\title{
Zooplankton in littoral waters of a tropical lake: a revisited biodiversity
}

\author{
Maia-Barbosa, PM.*, Peixoto, RS. and Guimarães, AS. \\ Laboratório de Ecologia do Zooplâncton, ICB/I3/253, Departamento de Biologia Geral, \\ Instituto de Ciências Biológicas, Universidade Federal de Minas Gerais - UFMG, \\ Av. Antônio Carlos, 6627, Pampulha, CEP 31270-901, Belo Horizonte, MG, Brazil \\ *e-mail: maia@mono.icb.ufmg.br
}

Received October 17, 2007 - Accepted October 17, 2007 - Distributed November 30, 2008

(With 2 figures)

\begin{abstract}
The present study was carried out in Lake Dom Helvécio, in the state of Minas Gerais, with two main objectives: to demonstrate the contribution of the littoral zone, in order to better characterize zooplankton fauna; and to assess the distribution of zooplankton species in different habitats, i.e., the littoral zone with and without aquatic vegetation. The samples were collected in February and July 2006, throughout the littoral zone of the lake, in areas with and without aquatic vegetation. We identified a total of 188 species, of which 130 are new records for Lake Dom Helvécio. One hundred and eighty-four species were identified in the littoral zone with aquatic vegetation, and 117 in the zone with no vegetation. The higher zooplankton richness in areas of the littoral zone with aquatic vegetation can be related to the greater environmental heterogeneity. Compared to previous studies on the littoral zones of lakes along the middle River Doce, the present study expended greater sampling effort, and identified many more species. In relation to biological conservation, this study demonstrated the importance of the littoral zone for better characterization and conservation of the zooplankton fauna, especially when it is colonized by aquatic vegetation. Underestimating the richness of species may provide inaccurate data on the biota, as well as on the ecological conditions in an environment.
\end{abstract}

Keywords: zooplankton, littoral zone, Lake Dom Helvécio, species richness.

\section{Zooplâncton da região litorânea de um lago tropical: a biodiversidade revisitada}

\begin{abstract}
Resumo
O presente estudo foi realizado no lago Dom Helvécio (MG) tendo como principais objetivos: demonstrar a contribuição da região litorânea para uma melhor caracterização da fauna zooplanctônica, avaliar a distribuição destas espécies em diferentes habitats (região litorânea com e sem vegetação aquática). As amostras foram coletadas nos meses de fevereiro e julho de 2006, ao longo da região litorânea, em pontos amostrais com e sem vegetação aquática. Um total de 188 espécies foi identificado. Desses organismos, 130 representaram novos registros para o lago Dom Helvécio. Foram identificadas 184 espécies na região litorânea com vegetação aquática e 117 na região litorânea sem vegetação. A maior riqueza em espécies zooplanctônicas na região litorânea com vegetação aquática está relacionada com a maior heterogeneidade ambiental. Quando comparado aos estudos realizados anteriormente na região litorânea de lagos do médio rio Doce, este estudo destaca-se pelo maior esforço amostral e número de espécies identificadas. No tocante à conservação biológica, o presente estudo mostrou a importância da região litorânea, especialmente quando colonizada por vegetação aquática para uma melhor caracterização e conservação da fauna zooplanctônica. A riqueza em espécies subestimada pode fornecer dados irreais sobre a biota, bem como das condições ecológicas de um ambiente.
\end{abstract}

Palavras-chave: zooplâncton, região litorânea, lago Dom Helvécio, riqueza em espécies.

\section{Introduction}

Fresh waters contain a rich and diverse fauna, with some groups occurring exclusively in these environments. Despite this, the number of species present in continental aquatic ecosystems is still not widely known, less than $30 \%$ of the biodiversity; existing studies are concentrated in certain groups that are considered economically

important, or are present in larger numbers, such as fish. Aquatic invertebrates form a very diverse group, play an important ecological role, participate directly in the processes that maintain the aquatic ecosystem (Purvis and Hector, 2000; Frouin and Lacobellis, 2003), and often act as bioindicators of the quality and health of eco- 
systems (Majer, 1987). Although 3,134 species of invertebrates have been identified in Brazilian fresh waters, it is estimated that approximately 8,000 non-recorded species must still exist (Rocha, 2003). Eskinazi-Sant'Anna et al. (2005), reviewing knowledge of the zooplankton biodiversity in the state of Minas Gerais, noted several factors that have contributed to the flaws in the knowledge of this fauna, such as the concentration of studies in certain hydrographic basins, the focus on certain taxonomic groups, and the lack of samples in lotic environments and littoral zones of lakes.

Within aquatic environments, the zooplankton fauna may vary greatly between the littoral and limnetic compartments. Several studies have demonstrated a higher richness in zooplankton species in littoral zones, especially when these are colonized by aquatic macrophytes (Pennak, 1966; Serrano and Toja, 1998; Lima et al., 2003). The authors attributed this richness to the greater environmental heterogeneity and wider spectrum of ecological niches, mainly compared to the limnetic zone. Despite this, knowledge of the diversity and biology of the animals of this zone is still sparse compared to those of the limnetic zone. Thus, the ecological requirements and the areas of occurrence of many species remain unknown. This lack of studies on zooplankton organisms in littoral waters of the tropics also applies to Lake Dom Helvécio. Although many aspects of this lake have been studied since 1970 , the majority of studies on the zooplankton community were carried out only in the limnetic zone.

Considering the large littoral area of Lake Dom Helvécio and the lack of studies on the zooplankton community in this compartment, the present study had two main objectives: to demonstrate the contribution of the littoral zone to a better characterization of the zooplankton fauna, and to assess these species' distribution in different habitats (littoral zone with and without aquatic vegetation).

\subsection{Study area}

Lake Dom Helvécio (Figure 1) is located in the Parque Estadual do Rio Doce, Minas Gerais, Brazil $\left(19^{\circ} 45^{\prime}-19^{\circ} 50^{\prime} \mathrm{S}\right.$ and $\left.42^{\circ} 35^{\prime}-42^{\circ} 40^{\prime} \mathrm{W}\right)$. It has an area of $6.87 \times 10^{6} \mathrm{~m}^{2}$, maximum depth of $32.5 \mathrm{~m}$, volume of $8.31 \times 10^{6} \mathrm{~m}^{3}$ and perimeter of $45,000 \mathrm{~m}$. Its dendritic shoreline is bordered almost entirely by riparian vegetation typical of the Atlantic Forest. The lake is oligotrophic, and is thermally stratified during summer (warm monomictic), with circulation from May to September. Most of the littoral zone is covered by large banks of aquatic macrophytes, such as Eleocharis interstincta, Typha domingensis, Eichornia crassipes and Nynphaea sp. (Ikusima and Gentil, 1997), as well as mixed banks.

\section{Material and Methods}

The samples were collected during the months of February and July 2006, at 16 locations throughout the littoral zone in each period, 10 colonized by the emer-

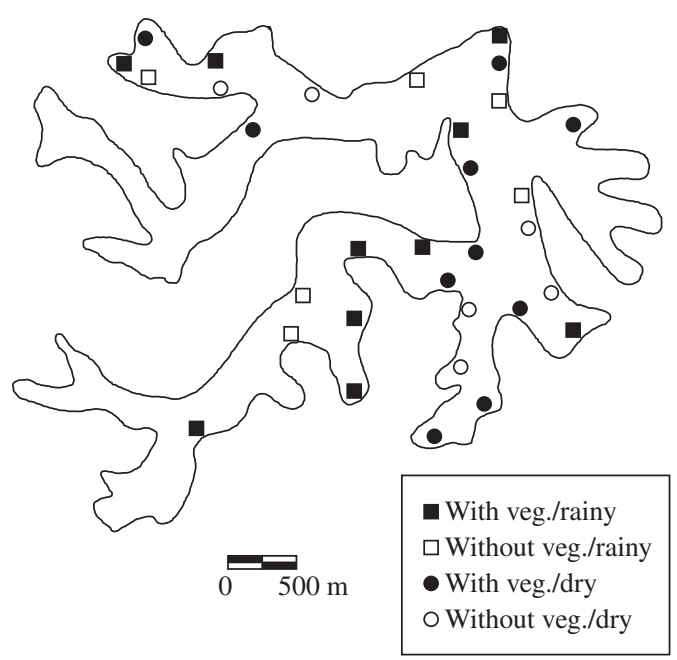

Figure 1. Study area and sampling stations.

gent aquatic macrophyte Eleocharis interstincta, and 6 without aquatic vegetation. The zooplankton samples were obtained at the subsurface, by filtering $200 \mathrm{~L}$ of water in a plankton net of $68 \mu \mathrm{m}$ mesh size. The samples were preserved in buffered $4 \%$ formaldehyde. The mesozooplankton (Copepoda and Cladocera) were counted in acrylic cuvettes under a stereoscopic microscope. The microzooplankton samples (Rotifera and testate amoebae) were counted in a Sedgwick-Rafter chamber, under an optical microscope, until the number of species stabilized. The organisms were identified whenever possible to species level, and in some cases as morphospecies, due to the lack of samples for more detailed taxonomic analysis. Different populations (varieties 1, 2 and 3) of Netzelia ovirformis were separated by observation of differentiated morphological aspects within the same species.

The water temperature, $\mathrm{pH}$, conductivity, and concentration of dissolved oxygen were measured with a Horiba U22 multi-analyzer. Water samples were also collected to determine the total nitrogen and total phosphorus concentrations, according to the recommendations of Mackereth et al. (1978). The differences in species richness between the littoral zones with and without aquatic vegetation were assessed by the Mann-Whitney test. This analysis was done using the program STATISTICA 6.0.

\section{Results}

Table 1 shows the mean values of the limnological variables of the littoral zones with and without aquatic vegetation, during the rainy (February) and dry (July) seasons of 2006. The waters were well oxygenated (from 6.56 to $11.15 \mathrm{mg} . \mathrm{L}^{-1}$ ), with a $\mathrm{pH}$ from 5.85 to 8.27 , low levels of conductivity (from 47 to $53 \mu \mathrm{S} . \mathrm{cm}^{-1}$ ), and higher temperatures during the rainy season. Higher values, mainly of the total nitrogen and total phosphorus concentrations, were usually recorded during the dry sea- 
Table 1. Mean values of Temperature, $\mathrm{pH}$, Conductivity, Dissolved Oxygen, Total Nitrogen, and Total Phosphorus in sections of the littoral zone with or without aquatic vegetation in Lake Dom Helvécio (PERD-MG), in February and July 2006.

\begin{tabular}{lccccc}
\hline \multirow{2}{*}{ Variables } & \multicolumn{2}{c}{ Rainy season } & & \multicolumn{2}{c}{ Dry season } \\
\cline { 2 - 3 } \cline { 5 - 6 } & With & Without & & With & Without \\
\hline Temperature $\left({ }^{\circ} \mathrm{C}\right)$ & 32.30 & 32.40 & & 24.50 & 24.40 \\
$\mathrm{pH}$ & 6.45 & 6.18 & & 7.52 & 7.85 \\
Conductivity $\left(\mu \mathrm{S} . \mathrm{cm}^{-1}\right)$ & 47 & 47 & & 53 & 53 \\
Dissolved Oxygen $\left(\mathrm{mg} . \mathrm{L}^{-1}\right)$ & 10.15 & 10.29 & & 7.45 & 7.50 \\
Total Nitrogen $\left(\mu \mathrm{g} . \mathrm{L}^{-1}\right)$ & 659.80 & 698.75 & & 1342.25 & 1254.50 \\
Total Phosphorus $\left(\mu \mathrm{g} . \mathrm{L}^{-1}\right)$ & 16.39 & 17.59 & & 23.05 & 23.77 \\
\hline
\end{tabular}

son. The differences between the recorded values were greater between the analyzed periods than between the zones with and without aquatic vegetation.

A total of 188 zooplankton species were identified, 93 being Rotifera, 48 testate amoebae, 32 Cladocera, and 16 Copepoda. Comparing these data to those from previous studies (Santos, 1980; Matsumura-Tundisi and Okano, 1983; Matsumura-Tundisi, 1997; Brito, 2003; data bank of the Programa de Pesquisas Ecológicas de Longa Duração-PELD), we noticed that 130 represent new records for Lake Dom Helvécio (Table 2): 51 Rotifera, 47 testate amoebae, 22 Cladocera, and 9 Copepoda.

Between the Copepoda, in the order Cyclopoida, 7 new records were established, plus 2 for Harpacticoida. There were no new records for the Calanoida. For Cladocera, 14 new species were recorded for the family Chydoridae, 4 for Daphnidae, 3 for Macrothricidae, and 1 for Sididae. There were no new records of Bosminidae or Ilyocryptidae.

The phylum Rotifera included a total of 18 families, of which 13 were new records: Brachionidae (3 new records), Colurellidae (11), Dicranophoridae (1), Euchlanidae (4), Gastropodidae (1), Lecanidae (17), Mytilinidae (2), Notomatidae (2), Synchaetidae (1), Testudinellidae (2), Trichocercidae (5), Trichotriidae (3), and Philodinidae (1). The families Collurelidae, Brachionidae and Lecanidae contributed the largest numbers of species.

The testate amoebae contributed nine families. Only one species, Arcella vulgaris, had been recorded prior to the present study.

One hundred and eighty-four species were identified in the littoral zone with aquatic vegetation, and 117 in the littoral zone without aquatic vegetation (Table 2). This difference was statistically significant (Figure 2), during both the rainy season (Mann-Whitney test; $\mathrm{U}=0.00$, $\mathrm{Z}=3.25, \mathrm{P}=0.001$ ) and the dry season (Mann-Whitney test; $\mathrm{U}=8.5, \mathrm{Z}=2.33, \mathrm{P}=0.02$ ). This study is different from the previous ones carried out in littoral zones of lakes in the middle River Doce, in that it was richer in identified species and had a higher sampling effort (Table 3).
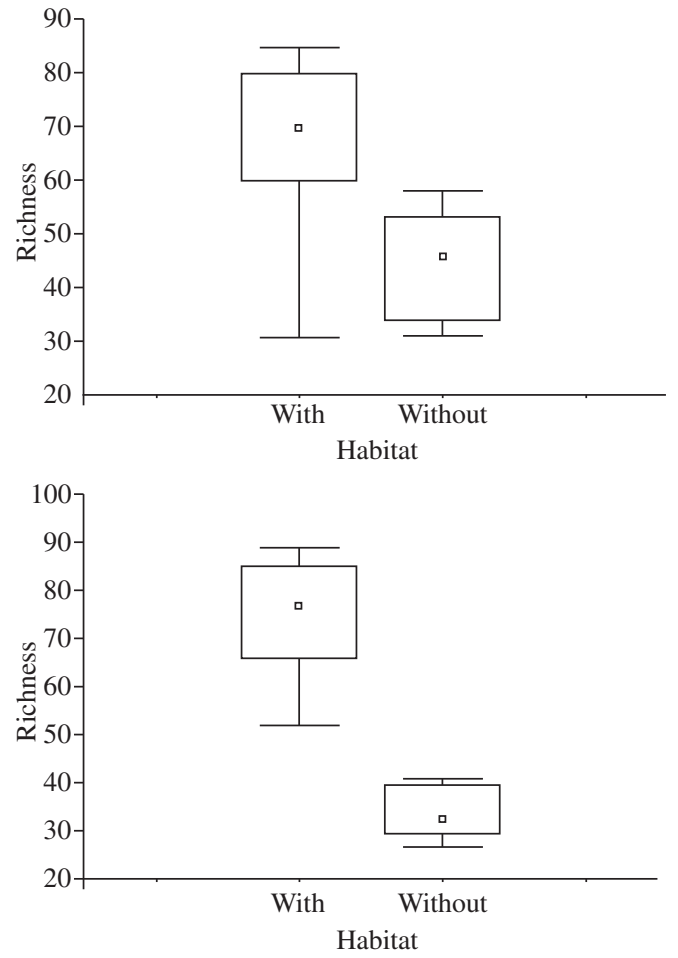

$$
\begin{aligned}
& \text { - Median 工 Non-outlier range } \\
& \square 25-75 \%
\end{aligned}
$$

Figure 2. Species richness in littoral habitat with and without aquatic vegetation in Lake Dom Helvécio: a) rainy, and b) dry in 2006 .

\section{Discussion}

According to Pandit (1984), the aquatic macrophytes have a stronger influence on the physical and chemical characteristics of the water than do the terrestrial plants on their environments. However, the lack of important differences in the limnological variables between the two types of littoral environments (littoral zones with and without aquatic vegetation) within the same period is probably due to daily water mixing along the horizontal axis, caused mainly by the wind. 
Table 2. Composition of zooplankton species in sections of the littoral zone with or without aquatic vegetation in Lake Dom Helvécio (PERD-MG), in February and July 2006.

\begin{tabular}{|c|c|c|}
\hline Taxon & With & Without \\
\hline \multicolumn{3}{|l|}{ COPEPODA } \\
\hline \multicolumn{3}{|l|}{ Calanoida } \\
\hline Notodiaptomus isabelae (Wright, 1936) & $\mathrm{x}$ & \\
\hline \multicolumn{3}{|l|}{ Cyclopoida } \\
\hline Ectocyclops herbsti (Dussart, 1984)* & $\mathrm{x}$ & $\mathrm{x}$ \\
\hline Ectocyclops rubescens (Brady, 1904)* & $\mathrm{x}$ & \\
\hline Homocyclops ater (Herrick, 1882)* & $\mathrm{x}$ & \\
\hline Macrocyclops albidus (Jurine, 1820)* & $\mathrm{x}$ & $\mathrm{x}$ \\
\hline Mesocyclops longisetus (Thiébaud, 1912) & $\mathrm{x}$ & $\mathrm{x}$ \\
\hline Mesocyclops ogunnus (Onabamiro, 1957)* & $\mathrm{x}$ & \\
\hline Mesocyclops meridianus (Kiefer, 1926) & $\mathrm{x}$ & \\
\hline Microcyclops alius (Kiefer, 1935)* & $\mathrm{x}$ & $\mathrm{x}$ \\
\hline Microcylops anceps (Richard, 1897) & $\mathrm{x}$ & $\mathrm{x}$ \\
\hline Neutrocyclops brevifurca (Lowndes, 1934)* & $\mathrm{x}$ & \\
\hline Paracyclops chiltoni (Thomson, 1882) & $\mathrm{x}$ & \\
\hline Thermocyclops minutus (Lowndes, 1934) & $\mathrm{x}$ & $\mathrm{x}$ \\
\hline Tropocyclops prasinus (Fischer, 1860) & $\mathrm{x}$ & $\mathrm{x}$ \\
\hline \multicolumn{3}{|l|}{ Harpacticoida } \\
\hline Attheyella fuhrmani (Thiébaud, 1912)* & $\mathrm{x}$ & $\mathrm{x}$ \\
\hline Elaphoidella sp.* & $\mathrm{x}$ & \\
\hline \multicolumn{3}{|l|}{ CLADOCERA } \\
\hline \multicolumn{3}{|l|}{ Bosminidae } \\
\hline Bosmina hagmanni (Stingelin, 1903) & $\mathrm{x}$ & $\mathrm{x}$ \\
\hline Bosmina tubicen (Brehm, 1956) & $\mathrm{x}$ & $\mathrm{x}$ \\
\hline Bosminopsis deitersi (Richard, 1895) & $\mathrm{x}$ & $\mathrm{x}$ \\
\hline \multicolumn{3}{|l|}{ Chydoridae } \\
\hline Alona cambouei (Guerne and Richard, 1903)* & $\mathrm{x}$ & \\
\hline Alona guttata (Sars, 1862)* & $\mathrm{x}$ & $\mathrm{x}$ \\
\hline Alona poppei (Richard, 1897)* & $\mathrm{x}$ & \\
\hline Alonella clathratula (Sars, 1896)* & $\mathrm{x}$ & \\
\hline Alonella lineollata (Sars, 1901)* & $\mathrm{x}$ & \\
\hline Biapertura verrucosa (Sars, 1901)* & $\mathrm{x}$ & $\mathrm{x}$ \\
\hline Chydorus eurynotus (Sars, 1901) & $\mathrm{x}$ & $\mathrm{x}$ \\
\hline Chydorus sphaericus (Müller, 1785) & $\mathrm{x}$ & $\mathrm{x}$ \\
\hline Dadaya macrops (Daday, 1898)* & $\mathrm{x}$ & $\mathrm{x}$ \\
\hline Disparalona dadayi (Birge, 1910)* & $\mathrm{x}$ & $\mathrm{x}$ \\
\hline Dunhevedia odontoplax (Sars, 1901)* & $\mathrm{x}$ & \\
\hline Ephemeroporus barroisi (Richard, 1894) & $\mathrm{x}$ & $\mathrm{x}$ \\
\hline Ephemeroporus tridentatus (Bergamin, 1939)* & $\mathrm{x}$ & $\mathrm{x}$ \\
\hline Leydigiopsis curvirostris (Sars, 1901)* & $\mathrm{x}$ & \\
\hline Leydigiopsis ornata (Daday 1905)* & $\mathrm{x}$ & \\
\hline Notoalona sculpta (Sars, 1901)* & $\mathrm{x}$ & \\
\hline Oxyurella ciliata (Bergamin, 1939)* & $\mathrm{x}$ & $\mathrm{x}$ \\
\hline \multicolumn{3}{|l|}{ Daphnidae } \\
\hline Ceriodaphnia cornuta (Sars, 1886) & $\mathrm{x}$ & $\mathrm{x}$ \\
\hline Ceriodaphnia silvestrii (Daday 1902)* & $\mathrm{x}$ & $\mathrm{x}$ \\
\hline Daphnia laevis (Birge, 1879)* & $\mathrm{x}$ & $\mathrm{x}$ \\
\hline Scapholeberis armata (Herrick, 1882)* & $\mathrm{x}$ & $\mathrm{x}$ \\
\hline Simocephalus serrulatus (Koch, 1841) & $\mathrm{x}$ & $\mathrm{x}$ \\
\hline
\end{tabular}


Table 2. Continued...

\begin{tabular}{|c|c|c|}
\hline Taxon & With & Without \\
\hline Simocephalus vetulus (Müller, 1776)* & $\mathrm{x}$ & \\
\hline \multicolumn{3}{|l|}{ Ilyocryptidae } \\
\hline Ilyocryptus spinifer (Herrick, 1882) & $\mathrm{x}$ & $\mathrm{x}$ \\
\hline \multicolumn{3}{|l|}{ Macrothricidae } \\
\hline Macrothrix flabeligera (Smirnov, 1992)* & $\mathrm{x}$ & $\mathrm{x}$ \\
\hline Macrothrix paulensis (Sars,1900)* & $\mathrm{x}$ & $\mathrm{x}$ \\
\hline Macrothrix spinosa (Sars, 1901)* & $\mathrm{x}$ & \\
\hline \multicolumn{3}{|l|}{ Sididae } \\
\hline Diaphanosoma birgei (Korinek, 1981) & $\mathrm{x}$ & $\mathrm{x}$ \\
\hline Pseudosida bidentada (Herrick, 1884)* & $\mathrm{x}$ & $\mathrm{x}$ \\
\hline \multicolumn{3}{|l|}{ ROTIFERA } \\
\hline \multicolumn{3}{|l|}{ Brachionidae } \\
\hline Anuraeopsis fissa (Gosse, 1851) & $\mathrm{x}$ & $\mathrm{x}$ \\
\hline Anuraeopsis navicula (Rousselet, 1911) & $\mathrm{x}$ & $\mathrm{x}$ \\
\hline Brachionus angularis (Gosse, 1851) & $\mathrm{x}$ & $\mathrm{x}$ \\
\hline Brachionus falcatus (Zacharias, 1898) & $\mathrm{x}$ & $\mathrm{x}$ \\
\hline Brachionus mirus (Daday, 1905) & $\mathrm{x}$ & $\mathrm{x}$ \\
\hline Brachionus patulus (Müller, 1953) & $\mathrm{x}$ & $\mathrm{x}$ \\
\hline Brachionus quadridentatus (Hermann, 1783) & $\mathrm{x}$ & $\mathrm{x}$ \\
\hline Kellicotia bostoniensis (Rousselet, 1908)* & $\mathrm{x}$ & $\mathrm{x}$ \\
\hline Keratella americana (Carlin, 1943) & $\mathrm{x}$ & $\mathrm{x}$ \\
\hline Keratella cochlearis (Gosse, 1851) & $\mathrm{x}$ & $\mathrm{x}$ \\
\hline Keratella lenzi (Hauer, 1953) & $\mathrm{x}$ & $\mathrm{x}$ \\
\hline Keratella tropica (Apstein, 1907) & $\mathrm{x}$ & $\mathrm{x}$ \\
\hline Keratella sp.* & $\mathrm{x}$ & $\mathrm{x}$ \\
\hline Platyas quadricornis var. brevispinus (Daday, 1905)* & & $\mathrm{x}$ \\
\hline \multicolumn{3}{|l|}{ Conochlidae } \\
\hline Conochillus coenobasis (Skorokov, 1914) & $\mathrm{x}$ & $\mathrm{x}$ \\
\hline \multicolumn{3}{|l|}{ Collothecidae } \\
\hline Collotheca sp. & $\mathrm{x}$ & $\mathrm{x}$ \\
\hline \multicolumn{3}{|l|}{ Colurellidae } \\
\hline Colurella sulcata (Stenroos, 1898)* & $\mathrm{x}$ & \\
\hline Colurella uncinata bicuspidata (Ehrenberg, 1832)* & $\mathrm{x}$ & $\mathrm{x}$ \\
\hline Lepadella cf. latusinus (Hilgendorf, 1899)* & $\mathrm{x}$ & \\
\hline Lepadella cristata (Rousselet, 1893) & $\mathrm{x}$ & \\
\hline Lepadella donneri (Koste, 1972)* & $\mathrm{x}$ & $\mathrm{x}$ \\
\hline Lepadella ovalis (O.F. Müller, 1786)* & $\mathrm{x}$ & $\mathrm{x}$ \\
\hline Lepadella patella (O.F. Müller, 1786)* & $\mathrm{x}$ & $\mathrm{x}$ \\
\hline Lepadella quinquecostata (Lucks, 1912)* & $\mathrm{x}$ & $\mathrm{x}$ \\
\hline Lepadella triptera (Ehrenberg, 1830)* & $\mathrm{x}$ & \\
\hline Lepadella triptera var. alata (Myers, 1934)* & $\mathrm{x}$ & \\
\hline Lepadella sp.* & $\mathrm{x}$ & \\
\hline Squatinella mutica (Ehrenberg,1832)* & $\mathrm{x}$ & \\
\hline \multicolumn{3}{|l|}{ Dicranophoridae } \\
\hline Dicranophorus epicharis (Harring and Myers, 1928)* & $\mathrm{x}$ & \\
\hline \multicolumn{3}{|l|}{ Euchlanidae } \\
\hline Dipleuchlanis propatula (Gosse, 1886)* & & $\mathrm{x}$ \\
\hline Euchlanis dilatata (Ehrenberg, 1832)* & $\mathrm{x}$ & $\mathrm{x}$ \\
\hline Euchlanis incisa (Carlin, 1939)* & $\mathrm{x}$ & \\
\hline Euchlanis meneta (Myers, 1930)* & $\mathrm{x}$ & $\mathrm{x}$ \\
\hline
\end{tabular}


Table 2. Continued...

\section{Taxon}

Filinidae

Filinea longiseta (Ehrenberg,1834)

Flosculariidae

Ptygura spp.

Sinantherina sp.

\section{$\mathrm{X}$}

$\mathrm{X}$

Gastropodidae

Ascomorpha saltans (Bartsch, 1870)*

Hexarthridae

Hexarthra intermedia (Wieszniewski, 1929)

Lecanidae

Lecane arcula (Harring, 1914)*

Lecane armata (Thomasson, 1971)*

Lecane braziliensis (Segers, 1993)*

Lecane bulla (Gosse, 1886)

Lecane closterocerca (Schmarda,1859)*

Lecane cornuta (O. F. Müller, 1786)*

Lecane crepida (Harring, 1914)*

Lecane curvicornis (Murray, 1913)

Lecane doryssa (Harring, 1914)*

Lecane furcata (Murray, 1913)*

Lecane halyclista (Harring and Myers, 1926)*

Lecane hamata (Stokes, 1896)

Lecane hornemanni (Ehrenberg, 1834)*

Lecane inermis (Bryce, 1892)*

Lecane leontina (Turner, 1892)

Lecane ludwigii (Eckstein, 1883)

Lecane lunaris (Ehrenberg, 1832)

Lecane monostyla (Daday, 1897)*

Lecane obtusa (Murray, 1913)*

Lecane psammophila (Wiszniewski, 1932)*

Lecane pussila (Lauterborn, 1898)*

Lecane pyriformis (Daday 1905)*

Lecane quadridentata (Ehrenberg,1832)

Lecane signifera (Jennings, 1896)*

Lecane sp. 1

Lecane sp. 2

Lecane sp.3

Lecane sp.4

Lecane sp.5

Lecane sp.6

Lecane sp.7

Mytilinidae

Lophocharis salpina (Ehrenberg, 1834)*

Mytilina ventralis macracantha (Gosse, 1886)*

Notomatidae

Cephalodella forfícula (Ehrenberg 1832)*

Cephalodella spp.

Monommata sp.*

Synchaetidae

Polyarthra vulgaris (Carlin, 1943)*

Polyarthra sp. 
Table 2. Continued...

Taxon

Without

Testudinellidae

Testudinella amphora (Hauer, 1938)*

Testudinella ohlei (Koste, 1972)

Testudinella patina (Hermann, 1783)*

Trichocercidae

Trichocerca cf. elongata (Gose, 1886)*

Trichocerca cylindrica chattoni (Beauchamp, 1907)*

Trichocerca iernis (Gosse, 1887)*

Trichocerca pusilla (Lauterborn, 1898)

Trichocerca rattus (O.F. Müller, 1776)*

Trichocerca similis (Wierzejski, 1893)*

Trichocerca sp.

Trichocerca stylata (Gosse, 1851)*

$\mathrm{X}$

$\mathrm{X}$

$\mathrm{X}$

$\mathrm{X}$

$\mathrm{X}$

$\mathrm{X}$

$\mathrm{X}$

$\mathrm{X}$

$\mathrm{X}$

$\mathrm{X}$

Trichotriidae

Macrochaetus collinsi (Gosse, 1867)*

Macrochaetus longipes (Myers, 1934)

Macrochaetus sericus (Thorpe, 1893)*

Tricotria tetractis (Ehrenberg, 1830)*

Bdelloidea

Philodinidae

Dissotrocha aculeata (Ehrenberg, 1832)*

\section{TESTACEA AMOEBA}

Arcellidae

Arcella conica (Playfair, 1917)*

Arcella costata (Ehrenberg, 1847)*

Arcella dentata (Ehrenberg, 1838)*

Arcella discoides (Ehrenberg, 1843)*

Arcella gibbosa (Pénard, 1890)*

Arcella hemisphaerica (Perty, 1852)*

Arcella megastoma (Pénard, 1902)*

Arcella rota (Daday, 1905)*

Arcella rotundata var. aplanata (Deflandre, 1928)*

Arcella vulgaris (Ehrenberg, 1830)*

Arcella vulgaris f. undulata (Deflandre, 1928 )*

Centropyxidae

Centropyxis hirsuta (Deflandre, 1929)*

Centropyxis aculeata (Ehrenberg, 1838)*

Centropyxis aerophila (Deflandre, 1929)*

Centropyxis cf. delicatula (Penard, 1902)*

Centropyxis constricta (Ehrenberg, 1841)*

Centropyxis discoides (Pénard, 1890)*

Centropyxis ecornis (Ehrenberg, 1841)*

Centropyxis gibba (Deflandre, 1929)*

Centropyxis minuta (Deflandre, 1929)*

Centropyxis sp.*

Centropyxis spinosa (Cash, 1905)*

Difflugiidae

Difflugia acuminata (Ehrenberg, 1838)* 
Table 2. Continued...

\begin{tabular}{|c|c|c|}
\hline Taxon & With & Without \\
\hline Difflugia lanceolata (Pénard, 1890)* & $\mathrm{x}$ & \\
\hline Difflugia oblonga (Ehrenberg, 1838)* & $\mathrm{x}$ & \\
\hline Difflugia stellastoma (Vucetich, 1989)* & & $\mathrm{x}$ \\
\hline Difflugia sp.* & $\mathrm{x}$ & $\mathrm{x}$ \\
\hline \multicolumn{3}{|l|}{ Cryptodifflugiidae } \\
\hline Difflugiella sp.* & $\mathrm{x}$ & $\mathrm{x}$ \\
\hline \multicolumn{3}{|l|}{ Euglyphidae } \\
\hline Euglypha acanthophora (Ehrenberg, 1841)* & $\mathrm{x}$ & $\mathrm{x}$ \\
\hline Euglypha brachiata (Leidy, 1878)* & $\mathrm{x}$ & \\
\hline Euglypha laevis (Ehrenberg, 1845)* & $\mathrm{x}$ & \\
\hline Euglypha strigosa (Ehrenberg, 1871)* & $\mathrm{x}$ & $\mathrm{x}$ \\
\hline Euglypha tuberculata (Dujardin 1841)* & $\mathrm{x}$ & \\
\hline Trinema enchelys (Ehrenberg, 1838)* & $\mathrm{x}$ & \\
\hline \multicolumn{3}{|l|}{ Hyalosphenidae } \\
\hline Nebela sp. & $\mathrm{x}$ & \\
\hline \multicolumn{3}{|l|}{ Lesquereusiidae } \\
\hline Lesquereusia modesta (Rhumbler, 1896)* & $\mathrm{x}$ & $\mathrm{x}$ \\
\hline Lesquereusia spiralis (Ehrenberg, 1840)* & $\mathrm{x}$ & \\
\hline Lesquereusia spiralis hirsuta (L. Gauthier-Lièvre, 1958) & $\mathrm{x}$ & \\
\hline Netzelia oviformis var.1 (Cash, 1909)* & $\mathrm{x}$ & $\mathrm{x}$ \\
\hline Netzelia oviformis var.2 (Cash, 1909)* & $\mathrm{x}$ & \\
\hline Netzelia oviformis var.3 (Cash, 1909)* & $\mathrm{x}$ & \\
\hline Netzelia wailesi (Ogden, 1980)* & $\mathrm{x}$ & $\mathrm{x}$ \\
\hline Quadrulella symmetrica (Wallich, 1863)* & $\mathrm{x}$ & \\
\hline \multicolumn{3}{|l|}{ Phryganellidae } \\
\hline Phryganella dissimulatoris (Chardez, 1969)* & $\mathrm{x}$ & \\
\hline \multicolumn{3}{|l|}{ Trigonopyxidae } \\
\hline Cyclopyxis kahli (Deflandre, 1929)* & $\mathrm{x}$ & \\
\hline
\end{tabular}

$*$ new record.

Table 3. Species richness and sampling effort in studies in the littoral zones of lakes along the middle River Doce, Minas Gerais.

\begin{tabular}{lccc}
\hline \multicolumn{1}{c}{ Author } & Species richness & No. samples & Environment studied \\
\hline Present study & 189 & 32 & Lake Dom Helvécio \\
Brito (2003) & 35 & 12 & Lake Dom Helvécio \\
Moretto (2001) & 60 & 26 & Lakes Carioca, Amarela, Aguapé, Águas Claras, Ariranha \\
Grimberg (2002) & 19 & 8 & Lake Baixa Verde \\
\hline
\end{tabular}

The larger the sampling effort, the better the prospect of sampling rare species. However, even when using intensive sampling strategies, the list of obtained species may be relatively incomplete, depending on the habitat (Muirhead et al., 2006). The zooplankton community of the pelagic zone of Lake Dom Helvécio was widely sampled by the PELD program (over a period of 7 years, with a total of 69 collections in the pelagic region) and by other extensive studies (Santos, 1980; Okano and Matsumura-Tundisi, 1983; Matsumura-Tundisi, 1997, with 6,6 and 1 collections, respectively). The large number of new records for the lake established in the present study was due simply to sampling in a poorly explored habitat, the littoral zone. Hence, the number of copepod species identified rose from 12 to 21 , of cladocerans from 18 to 40 , of rotifers from 60 to 112, and of testate amoebae from 1 to 48 . In view of these findings, in many aquatic ecosystems the zooplankton species richness may be underestimated, because the majority of studies are done in the pelagic zone. In a review of studies of the zooplankton community in Brazil, Rocha et al. (1995) reported that the theory of impoverishment of the cladoceran fauna in the tropics in relation to the temperate regions is due to the lack of studies in littoral zones. According to the authors, typically littoral and diverse taxa, such as members of the families Chydoridae and Macrothrycidae, are not included in the species list in the majority of the studies. 
The presence of vegetation is more important for the increase in species richness than the location of the collection, because of the greater complexity of this environment (Green, 1986). The higher zooplankton species richness in the littoral zone with aquatic vegetation is related to the greater environmental heterogeneity, since the aquatic vegetation provides aquatic invertebrates with more resources and refuges from predation (Pieczynska, 1990).

The periphyton community is developed on the submerged trunks and roots of floating macrophytes, and it constitutes a valuable food resource for the littoral zooplankton fauna. Another important food resource originating from aquatic macrophytes is organic detritus. A large portion of the biomass produced by aquatic macrophytes is transferred to other trophic levels through the detritus chain (Odum and de la Cruz, 1963; Esteves and Barbieri, 1983; Pagioro and Thomaz, 1999), since the herbivore chain has little influence on the aquatic macrophytes (Santos and Esteves, 2002). The testate amoebae are preferably associated with the vegetation above the sediment, and thus represent clear evidence of the influence of aquatic macrophytes on the distribution and richness of species, as demonstrated in the floodplain of the Paraná River by Velho et al. (1999).

Although physical and chemical conditions significantly influence the structure of the zooplankton community (Bertilsson et al., 1995), it was not possible to assess their contributions to the determination of the species richness gradient between the littoral zones with or without aquatic vegetation in the present study, because of the aforementioned similarities between these two environments.

The larger number of species recorded in this study in relation to previous studies in littoral zones of lakes along the middle River Doce can be explained mainly by the greater sampling effort and the presence of extensive aquatic macrophyte banks. Of the previous studies mentioned, only that of Brito (2003) was carried out in this same lake; Brito reported 35 zooplankton species, a relatively poor community, since in only one sampling locality of the present study 89 species were identified. Much of this difference may be related to the main focus of the previous study, which was the quantification of the zooplankton community biomass. Furthermore, the present study is the first to consider the testate amoebae in this environment; testate amoebae are a group with high diversity, mainly in aquatic vegetation.

In relation to biological conservation, the present study demonstrated the importance of the littoral zone, especially when colonized by aquatic vegetation, for a better characterization and conservation of the zooplankton fauna. Underestimating species richness may provide inaccurate data on the biota, as well as on the ecological conditions in an environment, leading to erroneous evaluation of the environmental impacts and/or conservation and management techniques, with serious implications for aquatic ecosystems.

\section{References}

BERTILSSON, J., BËRZINS, B. and PEJLER, B., 1995. Ocurrence of limnic micro-crustaceans in relation to temperature and oxygen. Hydrobiologia, vol. 299, no. 2, p. 163-167.

BRITO, SL., 2003. Composição, distribuição espacial $e$ biomassa do zooplâncton total do lago Dom Helvécio, Parque Estadual do Rio Doce-MG. Belo Horizonte: UFMG. 46 p.

ESKINAZI-SANT'ANNA, EM., MAIA-BARBOSA, PM., BRITO, SL. and RIETZLER, AC., 2005. Zooplankton Biodiversity of Minas Gerais State: a Preliminary Synthesis of Present Knowledge. Acta Limnol. Bras., vol. 17, no. 2, p. $199-218$.

ESTEVES, FA. and BARBIERI, R., 1983. Dry weight and chemical changes during decomposition of tropical macrophytes in Lobo reservoir- São Paulo, Brazil. Aquat. Bot., vol. 16, no. 3, p. 285-295.

FROUIN, R. and LACOBELLIS, S., 2003. The absorption power of plankton. Annual report of Scripps Institution of Oceanography, vol. 4, p. 2-3.

GREEN, J., 1986. Associations of zooplankton in six crater lakes in Arizona, Mexico and New Mexico. J. Zool., vol. 208, p. $138-159$.

GRIMBERG, EE., 2002. Estudo comparativo da comunidade zooplanctônica de um sistema artificial (Represa da Barra Bonita, SP) e de um sistema natural (Lagoa Baixa Verde, MG). São Carlos: EESC-USP. 272 p.

IKUSIMA, I. and GENTIL, JG., 1997. Ecological studies of aquatic macrophytes in four lakes. In JG. Tundisi and Y. Saijo (orgs.). Limnological Studies on the Rio Doce Valley Lakes, Brazil. Rio de Janeiro: Academia Brasileira de Ciências. p. 309-326.

LIMA, AF., LANSAC-TÔHA, FA., VELHO, LFM, BINI, LM. and TAKEDA, AM., 2003. Composition and abundance of Cladocera (Crustacea) assemblages associated to Eichhornia azurea (Swartz) Kunth in the Upper Paraná River floodplain. Acta Sci., vol. 25, no. 1, p. 41-48.

MACKERETH, FJH., HERON, J. and TALLING, JF., 1978. Water analysis and some revised methods for limnologists. New York, Freshwater Biological Association. 120 p.

MAJER, JD., 1987. Dealing with data from extensive invertebrates surveys. In MAJER, JD. (Ed.). The role of invertebrates in conservation and biological survey. Western Australia: Department of Conservation and Land Management. p. 53-64.

MATSUMURA-TUNDISI, T. and OKANO, WY., 1983. Seasonal fluctuation of copepod population in lake Dom Helvécio (Parque Florestal do Rio Doce, MG, Brazil). Rev. Hydrobiol. Trop., vol. 6, no. 1, p. 35-39.

MATSUMURA-TUNDISI, T., 1997. Composition and vertical distribution of zooplankton in lake Dom Helvécio- MG, Brazil. In TUNDISI, JG. and SAIJO, Y. (Orgs.). Limnological Studies on the Rio Doce Valley Lakes, Brazil. Rio de Janeiro: Academia Brasileira de Ciências. p. 309-326.

MORETTO, EM., 2001. Diversidade zooplanctônica e variáveis limnológicas das regiões limnética e litorânea de cinco lagoas do Rio Doce e sua relação com o entorno. São Carlos: UFSCAR. 268 p. 
MUIRHEAD, RJ., EJSMONT-KARABIN, J. and MACISAAC, JH., 2006. Quantifying rotifer species richness in temperate lakes. Freshwater Biology, vol. 51, no. 9, p. 1696-1709.

ODUM, EP. and DE LA CRUZ, AA., 1963. Detritus as a major component of ecosystems. Bioscience, vol. 13, no. 3, p. 39-40.

PAGIORO, TA. and THOMAZ, SM., 1999. Loss of weight and concentration of carbon, nitrogen, and phosphorus during decomposition of Eichhornia azurea in the floodplain of the upper Paraná river, Brazil. Rev. Bras. Biol. = Braz. J. Biol., vol. 58 , no. 4 , p. $603-608$.

PANDIT, AK., 1984. Role of macrophytes in aquatic ecosystems and management of water resources. J. Environ. Manag., vol. 18 , no. 1 , p. $73-88$.

PENNAK, PW., 1966. Structure of zooplankton populations in the littoral macrophyte zone of some Colorado lakes. Trans. Am. Microsc. Soc., vol. 85, no. 3 p. 329-349.

PIECZYNSKA, P., 1990. Littoral habitats and communities. In JORGENSEN, SE., and LÖFFLER, H. (Eds.). Guidelines of Lake Management. Lake shore management. International Lake Environment Committee. United Nations Environment Programme. p. 39-72.

PURVIS, A. and HECTOR, A., 2000. Getting the measure of biodiversity. Nature, vol. 405, p. 212-219.
ROCHA, O., 2003. Avaliação do estado do conhecimento da diversidade biológica do Brasil - Águas Doces. Projeto Estratégia Nacional de Diversidade Biológica (Bra 97 G 31). Brasília: Ministério do Meio Ambiente. 70 p

ROCHA, O., SENDACZ, S. and MATSUMURA-TUNDISI, T., 1995. Composition, biomass and productivity of zooplankton in natural lakes and reservoirs in Brazil. In TUNDISI, JG., BICUDO, CEM., and MATSUMURA-TUNDISI, T., (Eds.). Limnology in Brazil. Rio de Janeiro: Academia Brasileira de Ciências. p. 151-166.

SANTOS, AM. and ESTEVES, FA., 2002. Primary production and mortality of Eleocharis interstincta in response to water level fluctuations. Aquat. bot., vol. 74, no. 3, p. 189-199.

SANTOS, LC., 1980. Estudos das populações de Cladocera em cinco lagos naturais (Parque Florestal do Rio Doce-MG), que se encontram em diferentes estágios de evolução. São Carlos: UFSCAR. 260 p.

SERRANO, L. and TOJA, J., 1998. Interannual variability in the zooplankton community of a shallow temporary pond. Verh. Int. Ver. Limnol., vol. 26, p. 1575-1581.

VELHO, LFM., LANSAC-TÔHA, FA. and BINI, LM., 1999. Spatial and temporal variation in densities of testate amoebae in the plankton of the Upper Paraná River floodplain, Brazil. Hydrobiologia, vol. 411, p. 103-113. 